\title{
Design of a Helical Backbone. Conformation of Sequential Tridecapeptide Containing $Z$-Dehydrophenylalanine Residues
}

\author{
Yoshihito InaI, ${ }^{*}$ Kazuto Hasegawa, Tadamichi Hirabayashi, and Kenji Yokota \\ Department of Materials Science and Engineering, Nagoya Institute of Technology, \\ Gokiso-cho, Showa-ku, Nagoya 466, Japan
}

(Received June 28, 1995)

\begin{abstract}
Sequential peptides containing $Z$-dehydrophenylalanine $\left(\Delta^{Z} \mathrm{Phe}\right)$ residues, Boc- $\left(\mathrm{L}-\mathrm{Leu}-\Delta^{\angle} \mathrm{Phe}\right)_{n}$-L-Leu-OMe $(n=2-6)$, were synthesized, and their conformations in solution were investigated using ${ }^{1} \mathrm{H}$ NMR and CD spectroscopy. Tridecapeptide $(n=6)$ was shown to adopt a helical conformation in $\mathrm{CDCl}_{3}$ by observation of successive $\mathrm{N}_{i} \mathrm{H} \leftrightarrow \mathrm{N}_{i+1} \mathrm{H}$ nuclear Overhauser effects. Solvent accessibility of $\mathrm{NH}$ resonances for peptide $n=6$ in $\mathrm{CDCl}_{3}$ indicated that all the $\mathrm{NH}$ groups except those belonging to the $N$-terminal Leu- $A^{Z}$ Phe moiety participate in intramolecular hydrogen bonding. Similar accessibility was observed for peptides $n=2-5$. Thus, peptides $n=2-6$ in $\mathrm{CDCl}_{3}$ show a $(i+3) \rightarrow i$ intramolecular hydrogen bonding pattern characteristic of a 310 -helix. CD spectra of peptides $n=3 \quad 6$ in chloroform showed exciton couplets around $280 \mathrm{~nm}$ with a negative peak at longer wavelengths, corresponding to a right-handed helical sense. $\Delta^{Z}$ Phe residue was shown to be effective to design a $30_{10}$-helical-type backbone using sequential peptides of (X-A Phe) unit.
\end{abstract}

KEY WORDS Z-Dehydrophenylalanine / Sequential Oligopeptides / Nuclear Magnetic Resonance (NMR) Study / Circular Dichroism (CD) Study / $3_{10}$-Helical Conformation

$\alpha, \beta$-Dehydroamino acid residue is present naturally in many peptides having biological activity and in some proteins. ${ }^{1-5}$ This residue shows conformation that essentially differs from those of common amino acid residues due to its inherent structural features, e.g., the plarnarity of $\mathrm{C}^{\alpha}=\mathrm{C}^{\beta}$ double bond and trigonal geometry of $\alpha$-carbon atom. As for $Z$ - $\alpha, \beta$-dehydrophenylalanine $\left(\Delta^{Z} \mathrm{Phe}\right)$, linear oligopeptides containing two or three $\Lambda^{Z}$ Phe residues have been found in $3_{10^{-}}$or $\alpha$-helical structures. ${ }^{6-15}$ Such helical structures are due to steric interactions between main- and side-chains in $\Delta^{Z}$ Phe residue, although dehydro residues are essentially planar.<smiles>CN/C(=C/c1ccccc1)C(=O)[O-]</smiles>

$\Delta^{Z}$ Phe

$\Delta^{Z}$ Phe residue also shows conformational rigidity of its side chain due to prohibited rotation about $\mathrm{C}^{\alpha}=\mathrm{C}^{\beta}$ double bond.

Such $\beta$-substituted dehydroresidues will be useful to design helical backbones where rigid side chains $(\beta$ substituents) are regularly arranged, and thus provide a wide variety of functional polypeptides. However, little is known about conformational property of $\Delta^{Z}$ Phe residue in polypeptides: i.e., many conformational studies of $\Delta^{Z}$ Phe-containing peptides have focused on oligopeptides of relatively short chains ( $3-5$ residues), but not polypeptides. In addition, there has not been a systematic study of the chain-length effect on conformations of linear $\Delta^{Z}$ Phe-containing peptides.

To investigate the above points that are important from the viewpoint of polypeptide design using dehydroresidues, we synthesized sequential penta- to tridecapeptides containing $\Delta^{Z}$ Phe residues:

\footnotetext{
* To whom all correspondence should be addressed.
}

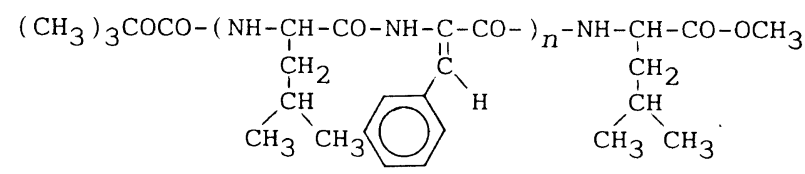

Boc-(L-Leu- $\Delta^{Z}$ Phe) ${ }_{n}$-L-Leu-OMe I- $n, n=2-6$

(Boc, $t$-butoxycarbonyl; OMe, methoxyl).

Pentapeptide Boc-X- $\Delta^{Z}$ Phe-X- $\Delta^{Z}$ Phe-X-OMe, an ana$\log$ of peptide I-2, takes a $31_{10}$-helix in solid state and solution. ${ }^{7,8,15}$ In the present paper, we focused mainly on the conformational analysis of longer tridecapeptide $\mathrm{I}-6$, i.e., whether such a long peptide retains a $33_{10}$-helix. The solution conformations of peptides I-2 to I- 6 were investigated by ${ }^{1} \mathrm{H}$ NMR and CD spectroscopy, and the conformation of $\triangle^{Z}$ Phe residue is discussed from the view point of rational design of helical backbones.

\section{EXPERIMENTAL}

\section{Materials}

Boc-Leu-OH and $\mathrm{HCl}$-Leu-OMe were prepared by the standard procedure. Boc-Leu- $\Delta^{Z}$ Phe-Leu-OMe (I-1) was introduced by ring-opening Boc-Leu- $\Delta^{Z}$ Phe azlactone with amino group of Leu-OMe. Likewise, peptide I- $n(n \geq 2)$ was prepared by ring-opening the azlactone with $N$-deprotected (Leu- $\left.\Delta^{Z} \mathrm{Phe}\right)_{n-1}$-Leu-OMe. All final peptides I- $n$ were checked by ${ }^{1} \mathrm{H}$ NMR and IR spectroscopy, thin-layer chromatography (TLC), and gel permeation chromatography (GPC). TLC was carried out on precoated silica plates in the following solvent systems: (A) ethyl acetate, (B) $\mathrm{CHCl}_{3}$-methanol (9:1), (C) $n$-butanol-acetic acid-water $(4: 1: 1)$. GPC was recorded on a Tosoh HLC-803-D equipped with G4000-, G3000-, and G2000-HLX columns in series, using tetrahydrofuran (THF) eluent. A single spot in the TLC and single peak in the GPC were obtained for each peptide, I- $n$. 
Boc-Leu- $\triangle^{Z}$ Phe Azlactone

Azlactone was prepared according to ref $9 . \mathrm{mp}$ $122-125^{\circ} \mathrm{C}\left(123-125^{\circ} \mathrm{C}\right) .^{9}$

\section{Boc-Leu- $\Delta^{Z}$ Phe-Leu-OMe (I-I)}

To a THF solution of Boc-Leu- $\Delta^{Z}$ Phe azlactone $(8.0 \mathrm{~g}, 22 \mathrm{mmol})$ were added $\mathrm{HCl} \cdot \mathrm{Leu}-\mathrm{OMe}(4.3 \mathrm{~g}$, $23 \mathrm{mmol}$ ) and triethylamine (TEA; $3.3 \mathrm{ml}, 23 \mathrm{mmol}$ ) at $0^{\circ} \mathrm{C}$. The mixture was stirred for $2 \mathrm{~h}$ at $0^{\circ} \mathrm{C}$ and then for $96 \mathrm{~h}$ at room temperature. The solvent was removed in vacuo and the residue was dissolved in ethyl acetate. The solution was washed successively with $5 \% \mathrm{KHSO}_{4}$, saturated $\mathrm{NaCl}, 5 \% \mathrm{NaHCO}_{3}$, and saturated $\mathrm{NaCl}$ solutions, and then dried over $\mathrm{MgSO}_{4}$. Crystallization from ethyl acetate/hexane gave I-1 as colorless crystals. Yield: $7.2 \mathrm{~g}(64 \%) ; \mathrm{mp} 187-187.5^{\circ} \mathrm{C} ; R_{\mathrm{f}}^{\mathrm{A}} 0.82 ; R_{\mathrm{f}}^{\mathrm{B}} 0.88$; $R_{\mathrm{f}}^{\mathrm{C}} 1.0$; retention time in GPC $\left(t_{\mathrm{R}}\right) 38.5 \mathrm{~min}$.

$90 \mathrm{MHz}{ }^{1} \mathrm{H}$ NMR $\left(\delta\right.$, in $\left.\mathrm{CDCl}_{3}\right): 7.5(1 \mathrm{H}, \mathrm{s}, \mathrm{NH}$ $\left.\Delta^{Z} \mathrm{Phe}\right), 7.2-7.5\left(6 \mathrm{H}, \mathrm{m}\right.$, aromatic $\mathrm{H}$ and $\left.\mathrm{C}^{\beta} \mathrm{H} \Delta^{Z} \mathrm{Phe}\right)$, $6.95(1 \mathrm{H}, \mathrm{d}, \mathrm{NH}$ Leu $), 4.6-5.0\left(2 \mathrm{H}, \mathrm{m}, \mathrm{C}^{\alpha}\right.$ Leu and $\mathrm{NH}$ $\left.\Delta^{\mathrm{Z}} \mathrm{Phe}\right), 4.1\left(1 \mathrm{H}, \mathrm{m}, \mathrm{C}^{\alpha} \mathrm{H} \mathrm{Leu}\right), 3.7\left(3 \mathrm{H}, \mathrm{s}, \mathrm{COOCH}_{3}\right)$, $1.5-1.8\left(6 \mathrm{H}, \mathrm{m}, 2 \times\left(\mathrm{C}^{\beta} \mathrm{H}_{2}-\mathrm{C}^{\gamma} \mathrm{H}\right.\right.$ Leu $\left.)\right), 1.4(9 \mathrm{H}, \mathrm{s}$, $\left.3 \times \mathrm{CH}_{3}\right), 0.95\left(12 \mathrm{H}, \mathrm{d}, 2 \times\left(2 \times \mathrm{CH}_{3} \mathrm{Leu}\right)\right)$. IR $\left(\mathrm{cm}^{-1}\right.$, on $\mathrm{NaCl})$ : $3350 / 3225(\mathrm{NH}), 1750 / 1720 / 1640(\mathrm{C}=\mathrm{O})$, and $1550 / 1500(\mathrm{NH})$.

\section{Boc- $\left(\text { Leu- } \Delta^{Z} \text { Phe }\right)_{2}$-Leu-OMe (I-2)}

Boc-Leu- $A^{Z}$ Phe-Leu-OMe $(6.5 \mathrm{~g}, 13 \mathrm{mmol})$ was dissolved in formic acid $(200 \mathrm{ml})$ and the solution was allowed to stand for $16 \mathrm{~h}$ at room temperature. The formic acid was evaporated in vacuo and dried. The residue $\left(\mathrm{HCOOH} \cdot \mathrm{Leu}-\Delta^{Z} \mathrm{Phe}-\mathrm{Leu}-\mathrm{OMe}\right)$ was dissolved in $N, N$-dimethylformamide (DMF; $20 \mathrm{ml}$ ), and to the solution were added Boc-Leu- $A^{Z}$ Phe azlactone $(5.5 \mathrm{~g}$, $15 \mathrm{mmol})$ and TEA $(1.8 \mathrm{ml}, 13 \mathrm{mmol})$ at $0^{\circ} \mathrm{C}$. The mixtures were stirred for $2 \mathrm{~h}$ at $0^{\circ} \mathrm{C}$ and for $60 \mathrm{~h}$ at room temperature. The solvent was removed in vacuo and the residue was dissolved in ethyl acetate. The solution was washed successively with $5 \% \mathrm{KHSO}_{4}$, saturated $\mathrm{NaCl}$, $5 \% \mathrm{NaHCO}_{3}$, and saturated $\mathrm{NaCl}$ solutions, and then dried over $\mathrm{MgSO}_{4}$.

The product was purified by elution through a silicagel column with ethyl acetate and then crystallized from ethyl acetate/hexane. Yield: $4.9 \mathrm{~g}(50 \%)$; mp 175.5$176^{\circ} \mathrm{C} ; R_{\mathrm{f}}^{\mathrm{A}} 0.80 ; R_{\mathrm{f}}^{\mathrm{B}} 0.55 ; R_{\mathrm{f}}^{\mathrm{C}} 0.92 ; t_{\mathrm{R}} 37.6 \mathrm{~min}$.

$400 \mathrm{MHz}{ }^{1} \mathrm{H}$ NMR $\left(\delta\right.$, in $\left.\mathrm{CDCl}_{3}\right): 8.66(1 \mathrm{H}, \mathrm{s}, \mathrm{NH}$ $\left.\Delta^{Z} \mathrm{Phe}\right), 7.74\left(1 \mathrm{H}, \mathrm{s}, \mathrm{NH} \Delta^{\mathrm{Z}} \mathrm{Phe}\right), 7.46(1 \mathrm{H}, \mathrm{d}, \mathrm{NH}$ Leu $)$, $7.17(1 \mathrm{H}, \mathrm{d}, \mathrm{NH}$ Leu $), 7.2-7.65(12 \mathrm{H}, \mathrm{m}$, aromatic $\mathrm{H}$ and $\left.\mathrm{C}^{\beta} \mathrm{H} \Delta^{Z} \mathrm{Phe}\right), 5.04(1 \mathrm{H}, \mathrm{s}, \mathrm{NH} \mathrm{Leu}), 4.67(1 \mathrm{H}, \mathrm{m}$, $\mathrm{C}^{\alpha} \mathrm{H}$ Leu $), 4.51$ (1H, m, C ${ }^{\alpha} \mathrm{H}$ Leu $), 3.93\left(1 \mathrm{H}, \mathrm{m}, \mathrm{C}^{\alpha} \mathrm{H}\right.$ Leu $), 3.7\left(3 \mathrm{H}, \mathrm{s}, \mathrm{COOCH}_{3}\right), 1.4-1.9\left(9 \mathrm{H}, \mathrm{m}, 3 \times\left(\mathrm{C}^{\beta} \mathrm{H}_{2}-\right.\right.$ $\mathrm{C}^{\gamma} \mathrm{H}$ Leu $), 1.46\left(9 \mathrm{H}, \mathrm{s}, 3 \times \mathrm{CH}_{3}\right), 0.9-1.0(18 \mathrm{H}, \mathrm{m}$, $\left.3 \times\left(2 \times \mathrm{CH}_{3} \mathrm{Leu}\right)\right)$. IR $\left(\mathrm{cm}^{-1}\right.$, on $\left.\mathrm{NaCl}\right): 3300(\mathrm{NH})$, $1740 / 1660 / 1630(\mathrm{C}=\mathrm{O})$, and $1520(\mathrm{NH})$.

\section{Boc- $\left(\text { Leu- } \Delta^{Z} \text { Phe }\right)_{3}$-Leu-OMe (I-3)}

Peptide I-3 was synthesized in a similar manner to peptide I-2, using peptide I-2 $(2.7 \mathrm{~g}, 3.5 \mathrm{mmol})$ and Boc-Leu- $\triangle^{\mathrm{Z}}$ Phe azlactone $(1.5 \mathrm{~g}, 4.2 \mathrm{mmol})$. Yield: $2.1 \mathrm{~g}$ $(58 \%) ; \operatorname{mp~} 214-215^{\circ} \mathrm{C} ; R_{\mathrm{f}}^{\mathrm{A}} 0.72 ; R_{\mathrm{f}}^{\mathrm{B}} 0.52 ; R_{\mathrm{f}}^{\mathrm{C}} 1.0 ; t_{\mathrm{R}}$ $36.9 \mathrm{~min}$.

$400 \mathrm{MHz}{ }^{1} \mathrm{H}$ NMR $\left(\delta\right.$, in $\left.\mathrm{CDCl}_{3}\right): 9.10(1 \mathrm{H}, \mathrm{s}, \mathrm{NH}$ $\left.\Delta^{Z} \mathrm{Phe}\right), 8.75\left(1 \mathrm{H}, \mathrm{s}, \mathrm{NH} \Delta^{Z} \mathrm{Phe}\right), 7.76\left(1 \mathrm{H}, \mathrm{s}, \mathrm{NH} \Delta^{\mathrm{Z}} \mathrm{Phe}\right)$,
$7.63(1 \mathrm{H}, \mathrm{d}, \mathrm{NH}$ Leu $), 7.47$ (1H, d, NH Leu), $7.37(1 \mathrm{H}$ d, NH Leu), 7.2-7.8 (18H, m, aromatic $\mathrm{H}$ and $\mathrm{C}^{\beta} \mathrm{H}$ $\Delta^{Z}$ Phe), 5.02 (1H, s, NH Leu), 4.65 (1H, m, $\mathrm{C}^{\alpha} \mathrm{H}$ Leu), 4.43 (1H, m, $\mathrm{C}^{\alpha} \mathrm{H}$ Leu $), 4.24$ (1H, m, $\mathrm{C}^{\alpha} \mathrm{H}$ Leu $), 3.74$ $\left(1 \mathrm{H}, \mathrm{m}, \mathrm{C}^{\alpha} \mathrm{H} \mathrm{Leu}\right), 3.74\left(3 \mathrm{H}, \mathrm{s}, \mathrm{COOCH}_{3}\right), 1.4-2.0$ $\left(12 \mathrm{H}, \mathrm{m}, 4 \times\left(\mathrm{C}^{\beta} \mathrm{H}_{2}-\mathrm{C}^{\gamma} \mathrm{H} \mathrm{Leu}\right)\right), 1.46\left(9 \mathrm{H}, \mathrm{s}, 3 \times \mathrm{CH}_{3}\right.$ Boc), $0.8-1.0\left(24 \mathrm{H}, \mathrm{m}, 4 \times\left(2 \times \mathrm{CH}_{3} \mathrm{Leu}\right)\right)$. IR $\left(\mathrm{cm}^{-1}\right.$, on $\mathrm{NaCl}): 3300(\mathrm{NH}), 1740 / 1660 / 1630(\mathrm{C}=\mathrm{O})$, and $1520(\mathrm{NH})$.

\section{Boc- $\left(\text { Leu- } \Delta^{Z} \text { Phe }\right)_{4}$-Leu-OMe (I-4)}

Peptide I-4 was synthesized in a similar manner to peptide I-2, using peptide I-3 $(1.2 \mathrm{~g}, 1.2 \mathrm{mmol})$ and Boc-Leu- ${ }^{Z}$ Phe azlactone $(0.5 \mathrm{~g}, 1.4 \mathrm{mmol})$. Yield: $0.85 \mathrm{~g}$ $(58 \%) ; \mathrm{mp} 150.5-152.5^{\circ} \mathrm{C} ; R_{\mathrm{f}}^{\mathrm{A}} 0.61 ; R_{\mathrm{f}}^{\mathrm{B}} 0.55 ; R_{\mathrm{f}}^{\mathrm{C}} 0.84$; $t_{\mathrm{R}} 36.3 \mathrm{~min}$.

$400 \mathrm{MHz}{ }^{1} \mathrm{H}$ NMR $\left(\delta\right.$, in $\left.\mathrm{CDCl}_{3}\right): 9.27(2 \mathrm{H}, \mathrm{s}, \mathrm{NH}$ $\left.\Delta^{Z} \mathrm{Phe}\right), 8.84\left(1 \mathrm{H}, \mathrm{s}, \mathrm{NH} \Delta^{Z} \mathrm{Phe}\right), 8.04\left(1 \mathrm{H}, \mathrm{s}, \mathrm{NH} \Delta^{Z} \mathrm{Phe}\right)$, $7.73(2 \mathrm{H}, \mathrm{s}, 2 \times \mathrm{NH}$ Leu $), 7.68(1 \mathrm{H}, \mathrm{d}, \mathrm{NH}$ Leu $), 7.41$ $(1 \mathrm{H}, \mathrm{d}, \mathrm{NH}$ Leu $), 7.25-7.65(24 \mathrm{H}, \mathrm{m}$, aromatic $\mathrm{H}$ and $\left.\mathrm{C}^{\beta} \mathrm{H} \Delta^{Z} \mathrm{Phe}\right), 5.31$ (1H, s, NH Leu), $4.62\left(1 \mathrm{H}, \mathrm{m}, \mathrm{C}^{\alpha} \mathrm{H}\right.$ Leu), $4.46\left(1 \mathrm{H}, \mathrm{m}, \mathrm{C}^{\alpha} \mathrm{H}\right.$ Leu $), 4.18\left(1 \mathrm{H}, \mathrm{m}, \mathrm{C}^{\alpha} \mathrm{H}\right.$ Leu $)$, $4.08\left(1 \mathrm{H}, \mathrm{m}, \mathrm{C}^{\alpha} \mathrm{H}\right.$ Leu $), 3.73\left(1 \mathrm{H}, \mathrm{t}, \mathrm{C}^{\alpha} \mathrm{H}\right.$ Leu $), 3.69(3 \mathrm{H}$, $\mathrm{s}, \mathrm{COOCH} 3), 1.5-2.1\left(15 \mathrm{H}, \mathrm{m}, 5 \times\left(\mathrm{C}^{\beta} \mathrm{H}_{2}-\mathrm{C}^{\gamma} \mathrm{H} \mathrm{Leu}\right)\right)$, $1.43\left(9 \mathrm{H}, \mathrm{s}, 3 \times \mathrm{CH}_{3}\right.$ Boc $), 0.85-1.0(30 \mathrm{H}, \mathrm{m}, 5 \times$ $\left.\left(2 \times \mathrm{CH}_{3} \mathrm{Leu}\right)\right)$. IR $\left(\mathrm{cm}^{-1}\right.$, on $\left.\mathrm{NaCl}\right): 3300(\mathrm{NH}), 1740 /$ $1660 / 1630(\mathrm{C}=\mathrm{O})$, and $1520(\mathrm{NH})$.

\section{Boc- $\left(\text { Leu- } \Delta^{\mathrm{Z}} \text { Phe }\right)_{5}$-Leu-OMe (I-5)}

Peptide I-5 was synthesized in a similar manner to peptide I-2, using peptide I-4 $(0.75 \mathrm{~g}, 0.58 \mathrm{mmol})$ and Boc-Leu- $\Delta^{Z}$ Phe azlactone $(0.25 \mathrm{~g}, 0.70 \mathrm{mmol})$. Yield: $0.79 \mathrm{~g}(88 \%) ; \mathrm{mp} 154-156^{\circ} \mathrm{C} ; R_{\mathrm{f}}^{\mathrm{A}} 0.57 ; R_{\mathrm{f}}^{\mathrm{B}} 0.56 ; R_{\mathrm{f}}^{\mathrm{C}}$ $0.87 ; t_{\mathrm{R}} 36.1 \mathrm{~min}$.

$400 \mathrm{MHz}{ }^{1} \mathrm{H} \mathrm{NMR}\left(\delta\right.$, in $\left.\mathrm{CDCl}_{3}\right): 9.37(1 \mathrm{H}, \mathrm{s}, \mathrm{NH}$ $\left.\Delta^{\mathrm{Z}} \mathrm{Phe}\right), 9.30\left(1 \mathrm{H}, \mathrm{s}, \mathrm{NH} \Delta^{\mathrm{Z}} \mathrm{Phe}\right), 9.28$ (1H, s, NH $\left.\Delta^{\mathrm{Z}} \mathrm{Phe}\right)$, $8.87\left(1 \mathrm{H}, \mathrm{s}, \mathrm{NH} \Delta^{Z} \mathrm{Phe}\right), 8.10\left(1 \mathrm{H}, \mathrm{s}, \mathrm{NH} \Delta^{Z} \mathrm{Phe}\right), 7.88$ $(1 \mathrm{H}, \mathrm{d}, \mathrm{NH}$ Leu $) 7.77(1 \mathrm{H}, \mathrm{d}, \mathrm{NH}$ Leu $), 7.74(1 \mathrm{H}, \mathrm{d}$, NH Leu), 7.68 (1 H, d, NH Leu), 7.44 (1 H, d, NH Leu), $7.20-7.65\left(30 \mathrm{H}, \mathrm{m}\right.$, aromatic $\mathrm{H}$ and $\left.\mathrm{C}^{\beta} \mathrm{H} \Delta^{Z} \mathrm{Phe}\right), 5.36$ $(1 \mathrm{H}, \mathrm{s}, \mathrm{NH}$ Leu $), 4.61\left(1 \mathrm{H}, \mathrm{m}, \mathrm{C}^{\alpha} \mathrm{H}\right.$ Leu $), 4.45(1 \mathrm{H}, \mathrm{m}$, $\mathrm{C}^{\alpha} \mathrm{H}$ Leu $), 4.19$ (1H, m, $\mathrm{C}^{\alpha} \mathrm{H}$ Leu), 4.08 (1H, m, $\mathrm{C}^{\alpha} \mathrm{H}$ Leu), 3.98 (1 H, m, $\mathrm{C}^{\alpha} \mathrm{H}$ Leu), $3.74\left(1 \mathrm{H}, \mathrm{t}, \mathrm{C}^{\alpha} \mathrm{H}\right.$ Leu $)$, $3.70\left(3 \mathrm{H}, \mathrm{s}, \mathrm{COOCH}_{3}\right), 1.5-2.1\left(18 \mathrm{H}, \mathrm{m}, 6 \times\left(\mathrm{C}^{\beta} \mathrm{H}_{2}\right.\right.$ $\mathrm{C}^{\gamma} \mathrm{H}$ Leu $), 1.46\left(9 \mathrm{H}, \mathrm{s}, 3 \times \mathrm{CH}_{3}\right.$ Boc $), 0.75-1.05(36 \mathrm{H}$, $\left.\mathrm{m}, 6 \times\left(2 \times \mathrm{CH}_{3} \mathrm{Leu}\right)\right)$. IR $\left(\mathrm{cm}^{-1}\right.$, on $\left.\mathrm{NaCl}\right): 3280(\mathrm{NH})$, $1740 / 1660 / 1630(\mathrm{C}=\mathrm{O})$, and $1530(\mathrm{NH})$.

\section{Boc- $\left(\text { Leu- } A^{Z} \text { Phe }\right)_{6}$-Leu-OMe (I-6)}

Peptide I-6 was synthesized in a similar manner to peptide I-2, using peptide I-5 $(0.50 \mathrm{~g}, 0.33 \mathrm{mmol})$ and Boc-Leu- $\Delta^{Z}$ Phe azlactone $(0.12 \mathrm{~g}, 0.33 \mathrm{mmol})$. Yield: $0.55 \mathrm{~g}(94 \%) ; \mathrm{mp} 242-244.5^{\circ} \mathrm{C} ; R_{\mathrm{f}}^{\mathrm{A}} 0.60 ; R_{\mathrm{f}}^{\mathrm{B}} 0.49 ; R_{\mathrm{f}}^{\mathrm{C}}$ $1.0 ; \quad t_{\mathrm{R}} 35.9 \mathrm{~min}$. The specific assignment of NMR spectrum will be shown later. IR $\left(\mathrm{cm}^{-1}\right.$, on $\left.\mathrm{NaCl}\right): 3280$ (NH), 1740/1660/1630 (C=O), and $1530(\mathrm{NH})$.

\section{Spectroscopy}

${ }^{1} \mathrm{H}$ NMR spectra were recorded using a Varian UNITY plus $400(400 \mathrm{MHz})$ and Hitachi R-90 spectrometer $(90 \mathrm{MHz})$. The measurement was carried out at a peptide concentration of $10-20 \mathrm{mg} \mathrm{ml}^{-1}$ in $\mathrm{CDCl}_{3}$ at $293 \mathrm{~K}$. All chemical shifts in parts per million (ppm) 


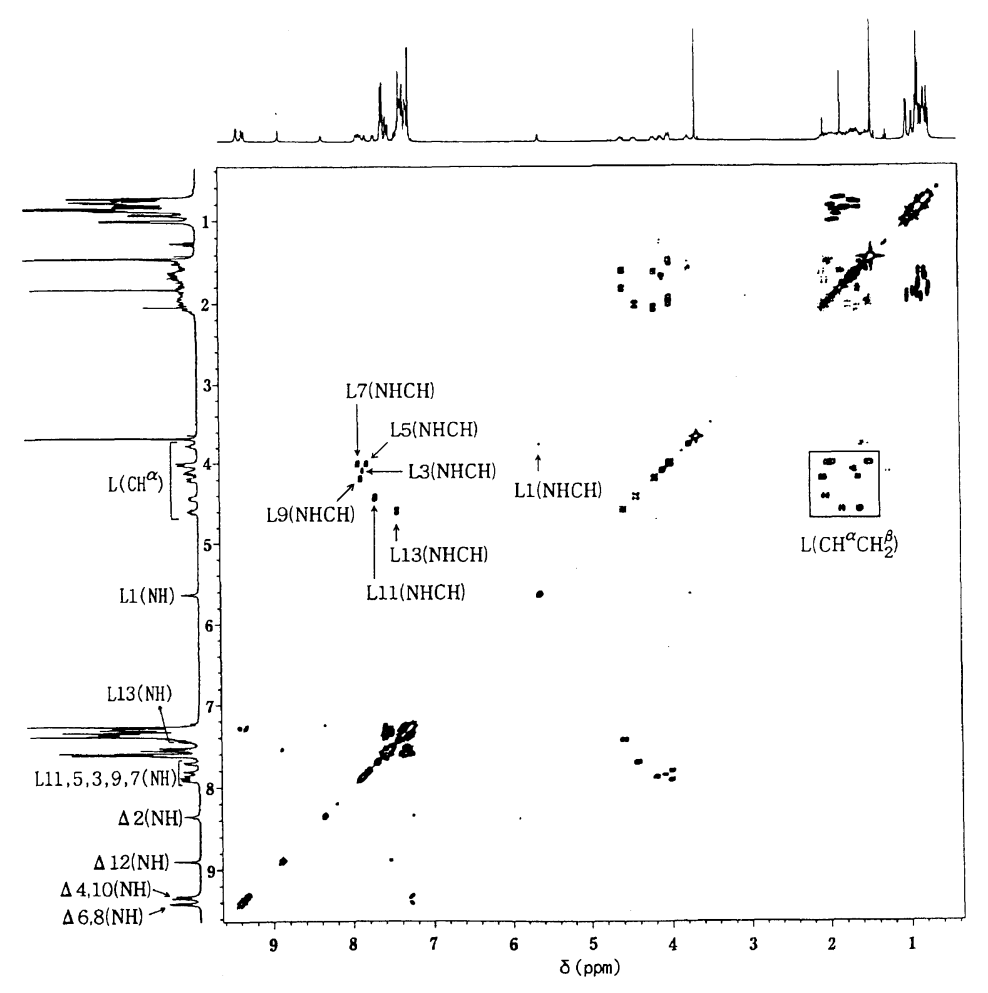

Figure 1. $400 \mathrm{MHz}$ COSY spectrum of peptide $\mathrm{I}-6$ in $\mathrm{CDCl}_{3}$. L and $\Delta$ are Leu and $\Delta^{z}$ Phe, respectively, and the number after $\mathrm{L}$ or $\Delta$ is the residue number from $N$-terminal. Assigned proton types are shown in parentheses.

are determined using tetramethylsilane as an internal standard. The pulse sequence for one-dimensional (1-D) $400 \mathrm{MHz}{ }^{1} \mathrm{H}$ NMR is as follows: $11.0-\mu$ s pulse width, 5.5-s acquisition time, and 7.5-s interval. Nuclear Overhauser effect (NOE) and correlation spectroscopy (COSY) experiments were performed using the standard Varian software library. NOE spectra were recorded as difference spectra using preirradiation time of $2 \mathrm{~s}$. COSY spectra were obtained using 16 scans per $t_{1}, 2 \mathrm{~K}$ data points in the $t_{2}$ domain, and 512 points in the $t_{1}$ domain. IR spectra were recorded for samples cast on an $\mathrm{NaCl}$ plate using a Jasco IR Report 100 spectrometer. CD and UV spectra were recorded simultaneously using a JASCO J-600 with $\Delta^{Z}$ Phe concentration of $5 \times 10^{-5} \mathrm{M}$. $\mathrm{CHCl}_{3}, \mathrm{THF}$, acetonitrile, methanol, trimethyl phosphate (TMP), dimethyl sulfoxide (DMSO), and trifluoroethanol (TFE) was used as the solvent, and purified by distillation before use.

\section{RESULTS AND DISCUSSION}

\section{Spectral Assignments of I-6}

Figure 1 shows two-dimensional $400 \mathrm{MHz}$ COSY spectrum with 1-D ${ }^{1} \mathrm{H}$ NMR spectra of I-6 in $\mathrm{CDCl}_{3}$. Seven Leu NHs could be found at $5.6-8.0 \mathrm{ppm}$ by observation of seven $\operatorname{Leu}(i) \quad \mathrm{NH} \leftrightarrow \operatorname{Leu}(i) \mathrm{C}^{\alpha} \mathrm{H}$ connectivities. Leu NH resonance at the highest field (5.4-5.6 ppm) was unambiguously assigned to urethane $\mathrm{NH},{ }^{16-19}$ i.e., $\mathrm{NH}$ of Leu(1) (the first residue from the $N$-terminal). Six singlets in the lower field $(8.3-9.5 \mathrm{ppm})$ are considered six $\Delta^{Z}$ Phe NHs due to the absence of $\mathrm{NH}-\mathrm{CH}^{\alpha}$ coupling. In general, $\Delta^{Z} \mathrm{Phe}$ NHs appeared at relatively lower fields. ${ }^{11,13-15}$ Moreover, the assignments of the six singlets to $\Delta^{Z}$ Phe NHs could be confirmed by difference NOE experiment. Here irradiation
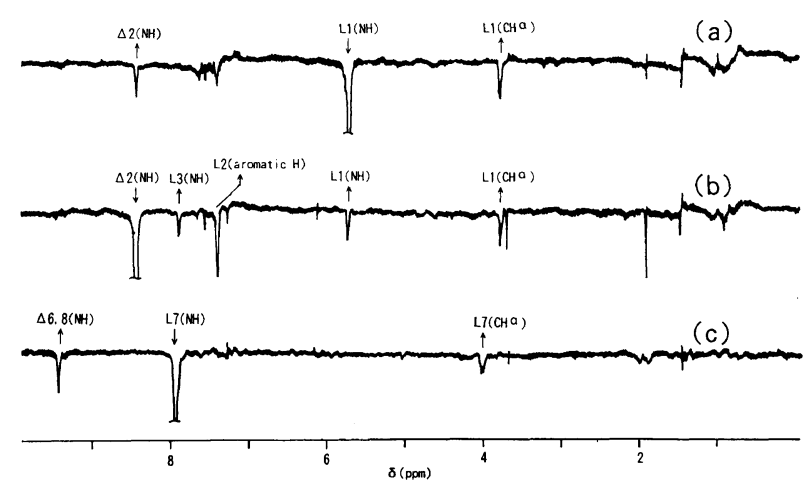

Figure 2. Difference NOE spectra obtained by irradiation of (a) Leu(1) NH, (b) $\Delta^{Z} \mathrm{Phe}(2) \mathrm{NH}$, and (c) Leu(7) NH. L and $\Delta$ are Leu and $\Delta^{Z} \mathrm{Phe}$, respectively, and number after $\mathrm{L}$ or $\Delta$ is the residue number from $N$-terminal. Proton types are shown in parentheses.

of each Leu NH resulted in enhancement of one or two singlet(s) among the six, indicating that the enhanced singlets belong to the neighboring residues, i.e., $\Delta^{Z} \mathrm{Phe}$ NHs.

Sequential assignment of all NH resonances was also made from difference NOE spectrum obtained by irradiation of each NH resonance. For example, Figure 2 shows the difference NOE spectra for irradiation of Leu(1) NH, $\Delta^{\mathrm{Z}} \mathrm{Phe}(2) \mathrm{NH}$, and Leu(7) NH resonances. First, irradiation of $\mathrm{Leu}(1) \mathrm{NH}$ resonance resulted in resonance enhancement of $\Delta^{Z}$ Phe $\mathrm{NH}(c a .8 .4 \mathrm{ppm})$ and of Leu $\mathrm{C}^{\alpha} \mathrm{H}$ ( $c a .3 .8 \mathrm{ppm}$ ). $\mathrm{NH}$ and $\mathrm{C}^{\alpha} \mathrm{H}$ can be assigned to $\Delta^{Z} \mathrm{Phe}(2) \mathrm{NH}$ and $\operatorname{Leu}(1) \mathrm{C}^{\alpha} \mathrm{H}$, respectively. Next, irradiation of $\Delta^{Z} \mathrm{Phe}(2) \mathrm{NH}$ led to enhancement of $\Delta^{Z} \mathrm{Phe}(1) \mathrm{NH}$, Leu(1) $\mathrm{C}^{\alpha} \mathrm{H}$, and Leu NH (at $c a .7 .9$ ppm), which can be assigned to Leu(3) NH. Similarly, each $\Delta^{Z}$ Phe NH and Leu NH were irradiated, and sequential assignment of enhanced $\mathrm{NH}$ resonances was 
made successively. Consequently, irradiation of each $\Delta^{Z}$ Phe(i) $\mathrm{NH}$ led to marked enhancement of two Leu NHs that can be assigned to the NHs of neighboring Leu residues, i.e., $\operatorname{Leu}(i-1)$ and $\operatorname{Leu}(i+1)$. Likewise, irradiation of each Leu(i) NH except two Leu NHs (Leu(1), and the other Leu at ca. $7.4 \mathrm{ppm}$ ) led to marked enhancement of two $\Delta^{Z} \mathrm{Phe} N \mathrm{NH}$ that can be assigned to the NHs of neighboring $\Delta^{Z}$ Phe residues, i.e., $\Delta^{Z} \mathrm{Phe}(i-1)$ and $\Delta^{Z} \mathrm{Phe}(i+1)$. On the other hand, enhancement of only $\Delta^{Z} \mathrm{Phe} \mathrm{NH}$ was observed by irradiating each of the two Leu NHs, which can be assigned to terminal Leu(1) and Leu(13). The NOE data are discussed for conformational analysis in the following.

Based on the above NMR results, 1-D $400 \mathrm{MHz}{ }^{1} \mathrm{H}$ NMR spectrum of I-6 in $\mathrm{CDCl}_{3}$ was assigned as follows: $9.41\left(2 \mathrm{H}, 2 \times \mathrm{s}\right.$, NHs $\Delta^{Z} \mathrm{Phe}(6)$ and $\left.\Delta^{Z} \mathrm{Phe}(8)\right), 9.34(1 \mathrm{H}$, s, NH $\left.\Delta^{Z} \mathrm{Phe}(10)\right), 9.32\left(1 \mathrm{H}, \mathrm{s}, \mathrm{NH} \Delta^{Z} \mathrm{Phe}(4)\right), 8.89(1 \mathrm{H}$, s, NH $\left.\Delta^{\mathrm{Z}} \mathrm{Phe}(12)\right), 8.1-8.4\left(1 \mathrm{H}, \mathrm{s}, \mathrm{NH} \Delta^{\mathrm{Z}} \mathrm{Phe}(2)\right), 7.91$ $(1 \mathrm{H}, \mathrm{d}, \mathrm{NH} \operatorname{Leu}(7)), 7.88(1 \mathrm{H}, \mathrm{d}, \mathrm{NH} \operatorname{Leu}(9)), 7.85-7.88$ $(1 \mathrm{H}, \mathrm{d}, \mathrm{NH} \operatorname{Leu}(3)), 7.80(1 \mathrm{H}, \mathrm{d}, \mathrm{NH} \operatorname{Leu}(5)), 7.70(1 \mathrm{H}$, d, NH Leu(11)), 7.43 (1H, d, NH Leu(13)), 7.2-7.6 (36H, m, aromatic $\mathrm{H}$ and $\left.\mathrm{C}^{\beta} \mathrm{H} \Delta^{\mathrm{Z}} \mathrm{Phe}\right), 5.45-5.65(1 \mathrm{H}$, s, NH Leu(1)), 4.59 (1H, m, C $\left.{ }^{\alpha} \mathrm{H} \operatorname{Leu}(13)\right), 4.42$ (1H, m, $\left.\mathrm{C}^{\alpha} \mathrm{H} \operatorname{Leu}(11)\right), 4.19\left(1 \mathrm{H}, \mathrm{m}, \mathrm{C}^{\alpha} \mathrm{H} \operatorname{Leu}(9)\right), 4.09(1 \mathrm{H}, \mathrm{m}$, $\left.\mathrm{C}^{\alpha} \mathrm{H} \operatorname{Leu}(3)\right), 4.00\left(2 \mathrm{H}, \mathrm{m}, \mathrm{C}^{\alpha} \mathrm{Hs} \operatorname{Leu}(5)\right.$ and $\left.\operatorname{Leu}(7)\right)$, $3.76\left(1 \mathrm{H}, \mathrm{m}, \mathrm{C}^{\alpha} \mathrm{H} \mathrm{Leu}(1)\right), 3.68\left(3 \mathrm{H}, \mathrm{s}, \mathrm{COOCH}_{3}\right)$, $1.4-2.2\left(14 \mathrm{H}, \mathrm{m}, \mathrm{C}^{\beta} \mathrm{H}_{2}\right), 1.5-2.1\left(21 \mathrm{H}, \mathrm{m}, 7 \times\left(\mathrm{C}^{\beta} \mathrm{H}_{2}\right.\right.$ $\mathrm{C}^{\gamma} \mathrm{H}$ Leu $\left.)\right), 1.45\left(9 \mathrm{H}, \mathrm{s}, 3 \times \mathrm{CH}_{3}\right.$ Boc $), 0.75-1.05(42 \mathrm{H}$, m, $7 \times\left(2 \times \mathrm{CH}_{3}\right.$ Leu $\left.)\right)$.

\section{Difference NOE of I-6}

Interproton NOEs can usually be used to specify proton pairs that are $\leq c a .3 \AA$ apart, and thus to confirm the presence of a specific conformation. In the present study, NOE spectra for irradiation of each $\mathrm{NH}$ resonance in I-6 were recorded in $\mathrm{CDCl}_{3}$ at $25^{\circ} \mathrm{C}$ as difference spectra. All NOEs observed here were negative, suggesting that the condition $\omega \tau_{\mathrm{c}}>1$ is satisfied. ${ }^{20}$ Table I shows NOEs observed for all NHs and Leu $\mathrm{C}^{\alpha} \mathrm{Hs}$ in peptide I-6 by irradiating each $\mathrm{NH}$ resonance. Appreciable NOEs $(4-10 \%)$ were observed for all
$\mathrm{N}_{i} \mathrm{H} \leftrightarrow \mathrm{N}_{i+1} \mathrm{H}$ pairs in peptide $\mathrm{I}-6$, indicating a short $\mathrm{N}_{i} \mathrm{H}-\mathrm{N}_{i+1} \mathrm{H}$ interproton distance $(d)$. In general, the short distance of $\mathrm{N}_{i} \mathrm{H}-\mathrm{N}_{i+1} \mathrm{H}$ should be ascribed to the presence of a $310^{\text {-helical }}(d=c a$. 2.6 $\AA$ ) or $\alpha$-helical $(d=c a .2 .8 \AA)$ conformation having main-chain torsional angles of $\phi \sim-50^{\circ}$ and $\psi \sim-50^{\circ} .{ }^{21}$

Relatively weak NOEs $(1-5 \%)$ were simultaneously observed for Leu(i) $\mathrm{C}^{\alpha} \mathrm{H} \leftrightarrow \Delta^{Z} \mathrm{Phe}(i+1) \mathrm{NH}$ pairs. $\mathrm{N}_{i} \mathrm{H} \leftrightarrow \mathrm{N}_{i+1} \mathrm{H}$ and $\mathrm{C}_{i}^{\alpha} \mathrm{H} \leftrightarrow \mathrm{N}_{i+1} \mathrm{H}$ pairs were seen in other helical $\Delta^{Z}$ Phe-containing oligopeptides. ${ }^{11,13}$ This may be interpreted in two ways as suggested by Chauhan et $a l .{ }^{11}$ First, their conformers involve not only a right-handed helical structure, but partly an extended structure. The two distinct conformers are considered in equilibrium of a weighted population of the two conformers, based on the intensities of the observed NOEs. Secondly, its conformation is essentially a left-handed helix, where both $\mathrm{C}_{i}^{\alpha} \mathrm{H} \leftrightarrow \mathrm{N}_{i+1} \mathrm{H}$ and $\mathrm{N}_{i} \mathrm{H} \leftrightarrow \mathrm{N}_{i+1} \mathrm{H}$ distances are short $(<3 \AA)$ enough to show marked NOEs. The reasonable interpretation should be conformational heterogeneity, since the left-handed helix is sterically disallowed for L-residue. In fact, CD spectrum of I-6 in $\mathrm{CHCl}_{3}$ indicated a right-handed helical conformation, as shown later. The helical structure as a major conformation is also supported by $J_{\mathrm{CH}} \alpha_{\mathrm{NH}}$ $(<6 \mathrm{~Hz})$ of Leu residues: $4.2 \mathrm{~Hz}$ for $\mathrm{Leu}(3), 3.0 \mathrm{~Hz}$ for $\operatorname{Leu}(5), 4.0 \mathrm{~Hz}$ for Leu(7), $4.1 \mathrm{~Hz}$ for Leu(9), and $5.7 \mathrm{~Hz}$ for Leu(11). These $J^{21}$ correspond to $\phi_{\text {Leu }} \sim-50^{\circ}$ to $-70^{\circ}$ characteristic of the $3_{10^{-}}$or $\alpha$-helical structure.

\section{Hydrogen-Bonding Pattern}

The NOE study indicated that peptide I-6 forms almost only the $3_{10^{-}}$or $\alpha$-helix. To determine helical type, the presence of hydrogen-bonded NH resonances was investigated by measuring the degree of solvent exposure of each $\mathrm{NH}$ group for a given peptide. ${ }^{22}$ In the present study, we used the solvent dependence of $\mathrm{NH}$ chemical shifts in $\mathrm{CDCl}_{3}-\mathrm{DMSO}-d_{6}{ }^{23}$ and/or dependence of paramagnetic radical, 2,2,6,6-tetramethylpiperidine-1-oxyl (TEMPO), on line broadening of NH resonances in $\mathrm{CDCl}_{3} \cdot{ }^{24}$

Figure 3(a) shows variation in NH chemical shifts for

Table I. Difference NOEs observed for peptide I- 6 in $\mathrm{CDCl}_{3}{ }^{a}$

$\%$ NOE for $\mathrm{NH}$ and $\mathrm{CH}^{\alpha}$ resonance of $(i)$ th residue from $\mathrm{N}$-terminal

\begin{tabular}{|c|c|c|c|c|c|c|c|c|c|c|c|c|c|c|c|c|c|c|c|c|}
\hline \multirow{2}{*}{$\begin{array}{l}\text { Irradiated } \\
\text { resonance }\end{array}$} & \multicolumn{2}{|c|}{$\begin{array}{l}\text { (1) } \\
\text { Leu }\end{array}$} & \multirow{2}{*}{$\begin{array}{c}(2) \\
\Delta^{Z} \mathrm{Phe} \\
\mathrm{NH}\end{array}$} & \multicolumn{2}{|c|}{$\begin{array}{l}\text { (3) } \\
\text { Leu }\end{array}$} & $\begin{array}{c}(4) \\
\Delta^{Z} \mathrm{Phe}\end{array}$ & \multicolumn{2}{|c|}{$\begin{array}{l}(5) \\
\text { Leu }\end{array}$} & $\begin{array}{c}(6) \\
\Delta^{Z} \mathrm{Phe}\end{array}$ & \multicolumn{2}{|c|}{$\begin{array}{l}\text { (7) } \\
\text { Leu }\end{array}$} & $\begin{array}{c}(8) \\
\Delta^{Z} \mathrm{Phe}\end{array}$ & \multicolumn{2}{|c|}{$\begin{array}{l}(9) \\
\text { Leu }\end{array}$} & $\begin{array}{c}(10) \\
\Delta^{Z} \text { Phe }\end{array}$ & \multicolumn{2}{|c|}{$\begin{array}{l}\text { (11) } \\
\text { Leu }\end{array}$} & \multirow{2}{*}{$\begin{array}{c}(12) \\
\Delta^{Z} \text { Phe } \\
\text { NH }\end{array}$} & \multicolumn{2}{|c|}{$\begin{array}{l}\text { (13) } \\
\text { Leu }\end{array}$} \\
\hline & $\mathrm{NH}$ & $\mathrm{CH}^{\alpha}$ & & $\mathrm{NH}$ & $\mathrm{CH}^{\alpha}$ & NH & $\mathrm{NH}$ & $\mathrm{CH}^{\alpha}$ & NH & $\mathrm{NH}$ & $\mathrm{CH}^{\alpha}$ & $\mathrm{NH}$ & NH & $\mathrm{CH}^{\alpha}$ & $\mathrm{NH}$ & $\mathrm{NH}$ & $\mathrm{CH}^{\alpha}$ & & $\mathrm{NH}$ & $\mathrm{CH}^{\alpha}$ \\
\hline Leu(1) NH & $x$ & 16.9 & 6.8 & & & & & & & & & & & & & & & & & \\
\hline$\Delta^{Z} \mathrm{Phe}(2) \mathrm{NH}$ & 6.0 & 5.9 & $x$ & * & & & & & & & & & & & & & & & & \\
\hline $\operatorname{Leu}(3 / 9) \mathrm{NH}$ & & & 1.5 & $x$ & 6.8 & 3.9 & & & & & & * & $x$ & 7.8 & 4.8 & & & & & \\
\hline$\Delta^{Z} \mathrm{Phe}(4) \mathrm{NH}$ & & 2.1 & & * & 3.2 & $x$ & 3.7 & & & & & & & & & & & & & \\
\hline Leu(5) NH & & & & & & 8.4 & $x$ & * & * & & & & & & & & & & & \\
\hline$\Delta^{Z} \mathrm{Phe}(6) \mathrm{NH}$ & & & & & 2.2 & & 3.7 & * & $x$ & 7.9 & & & & & & & & & & \\
\hline Leu(7) NH & & & & & & & & & * & $x$ & * & * & & & & & & & & \\
\hline$\Delta^{Z} \mathrm{Phe}(8) \mathrm{NH}$ & & & & & & & 1.2 & & & 6.9 & * & $x$ & 4.2 & 1.0 & & & & & & \\
\hline$\Delta^{Z} \mathrm{Phe}(10) \mathrm{NH}$ & & & & & & & & & & & * & & 8.9 & 2.9 & $x$ & 4.6 & & & & \\
\hline Leu(11) NH & & & & & & & & & & & & & & 3.1 & 5.6 & $x$ & 10.1 & 8.2 & & \\
\hline$\Delta^{Z} \mathrm{Phe}(12) \mathrm{NH}$ & & & & & & & & & & & & & & 4.7 & 1.8 & 7.3 & 4.8 & $x$ & 9.2 & \\
\hline Leu(13) NH & & & & & & & & & & & & & & & & & & 3.6 & $x$ & 5.2 \\
\hline
\end{tabular}

${ }^{\text {a }} \times$ shows irradiated proton. $*$ shows marked NOE, but its intensity could not be estimated due to overlap of other peaks. 


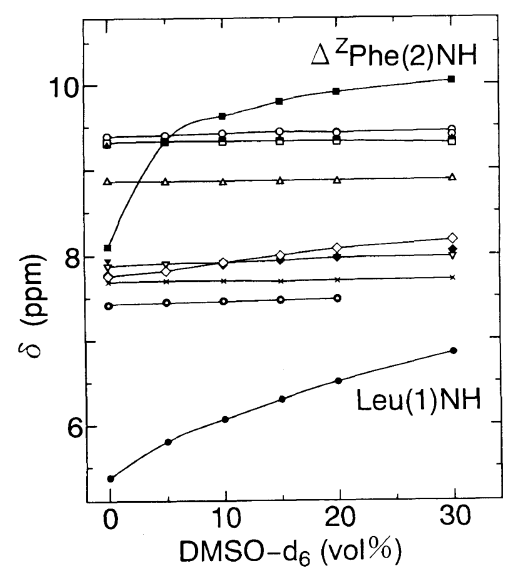

Figure 3(a). Solvent dependence of $\mathrm{NH}$ chemical shifts in peptide I-6 in $\mathrm{CDCl}_{3}-\left(\mathrm{CD}_{3}\right)_{2} \mathrm{SO}$ mixtures of varying concentrations. $\mathrm{NH}$ number from $N$-terminal: $1(\bullet) ; 2(\boldsymbol{\square}) ; 3(\diamond) ; 4(\boldsymbol{\Delta}) ; 5(\diamond) ; 6(\bigcirc) ; 7(\boldsymbol{\nabla}) ; 8(\bigcirc)$; $9(\nabla) ; 10(\square) ; 11(\times) ; 12(\triangle) ; 13(\odot)$.

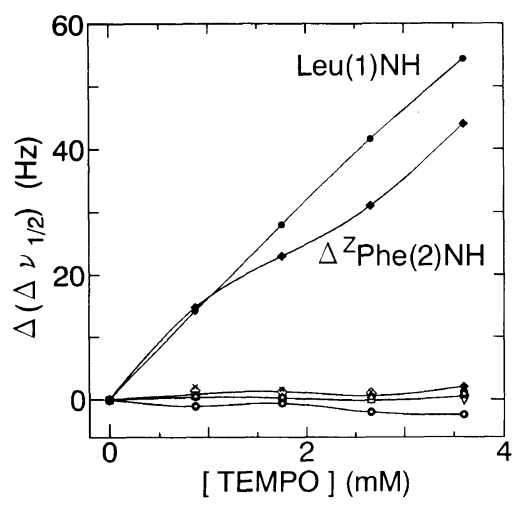

Figure 3(b). Dependence of NH resonance line width in peptide I-6 on the concentration of 2,2,6,6-tetramethylpiperidine (TEMPO) in $\mathrm{CDCl}^{3}$. NH number from $N$-terminal: $1(\bullet) ; 2(\diamond) ; 3(\diamond) ; 4(\boldsymbol{\Delta}) ; 5(\diamond)$; 6(○); 7( $) ; 8(\bigcirc) ; 9(\nabla) ; 10(\square) ; 11(\times) ; 12(\triangle) ; 13(\odot)$.

peptide I-6 with concentration of DMSO- $d_{6}$. Two NH resonances, Leu(1) $\mathrm{NH}$ and $\Delta^{\mathrm{Z}} \mathrm{Phe}(2) \mathrm{NH}$, markedly shifted to a lower field with increasing concentration of DMSO- $d_{6}$. These shifts can be ascribed to the absence of hydrogen-bonds in Leu(1) and $\Delta^{\mathrm{Z}} \mathrm{Phe}(2) \mathrm{NHs}$, but not to conformational change by DMSO, since CD spectra of peptide I-6 did not change in $0-9 \mathrm{vol} \%$ DMSO. The other eleven NHs, Leu(3) to Leu(13) NHs, were relatively unaffected by the addition of strong hydrogen accepting DMSO- $d_{6}$, and thus should be shielded from solvent due to intramolecular hydrogenbonding. Similar results were observed in radical perturbation experiments, as shown in Figure 3(b). There is thus pronounced line broadening of Leu(1) $\mathrm{NH}$ and $\Delta^{Z} \mathrm{Phe}(2) \mathrm{NH}$ resonances, while the other eleven NHs remain almost unaffected. These NMR results indicate that all NH groups except Leu(1) and $\Delta^{Z} \mathrm{Phe}(2) \mathrm{NHs}$ in $100 \% \mathrm{CDCl}_{3}$ participate in intramolecular hydrogen bonding. As shown in Scheme 1, this hydrogen-bonding pattern corresponds to $3_{10}$-helical-type $[(i+3) \rightarrow i]$ mode, but not to $\alpha$-helical-type $[(i+4) \rightarrow i]$ mode where all NH groups except Leu(1), $\Delta^{Z} \mathrm{Phe}(2)$, and Leu(3) NHs participate in intramolecular hydrogen bonding.

Figures $4-7$ show variation of $\mathrm{NH}$ chemical shifts for peptides I-2 to I-5 with concentration of DMSO- $d_{6}$ in $\mathrm{CDCl}_{3}$. Two NHs, Leu(1) and $\Delta^{Z} \mathrm{Phe} \mathrm{NHs}$, remarkably

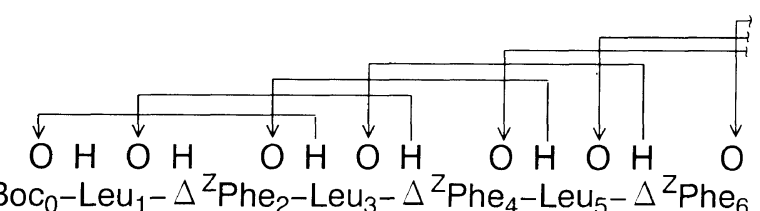

$3_{10}$-helical-type

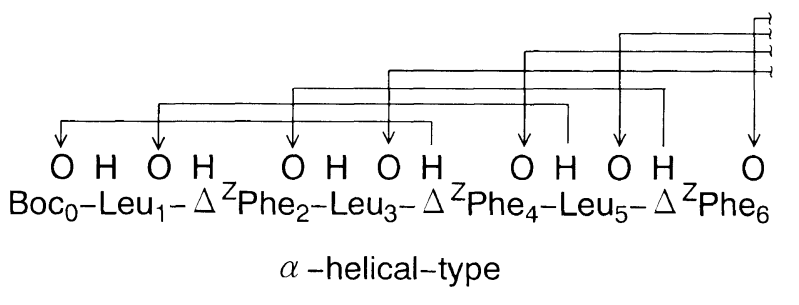

Scheme 1.

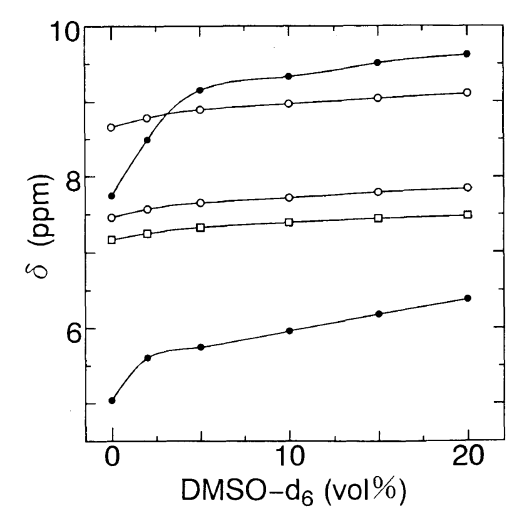

Figure 4. Solvent dependence of $\mathrm{NH}$ chemical shifts in peptide $\mathrm{I}-2$ in $\mathrm{CDCl}_{3}-\left(\mathrm{CD}_{3}\right)_{2} \mathrm{SO}$ mixtures of varying concentration.

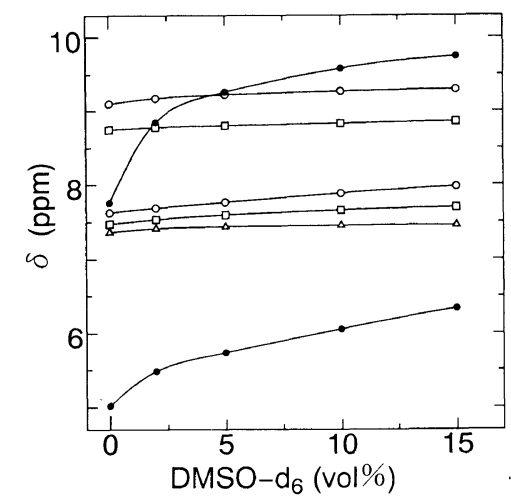

Figure 5. Solvent dependence of $\mathrm{NH}$ chemical shifts in peptide I-3 in $\mathrm{CDCl}_{3}-\left(\mathrm{CD}_{3}\right)_{2} \mathrm{SO}$ mixtures of varying concentration.

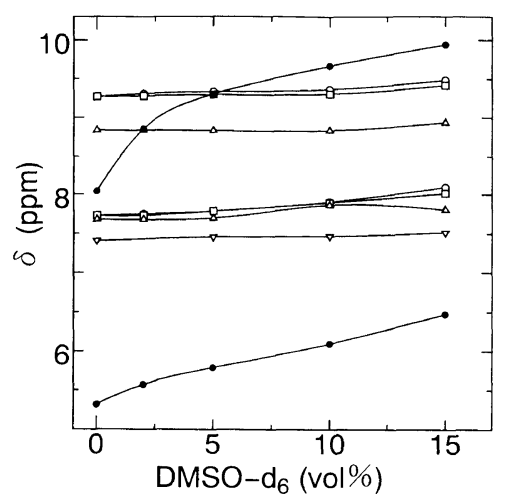

Figure 6. Solvent dependence of NH chemical shifts in peptide I-4 in $\mathrm{CDCl}_{3}-\left(\mathrm{CD}_{3}\right)_{2} \mathrm{SO}$ mixtures of varying concentration.

Polym. J., Vol. 28, No. 3, 1996 


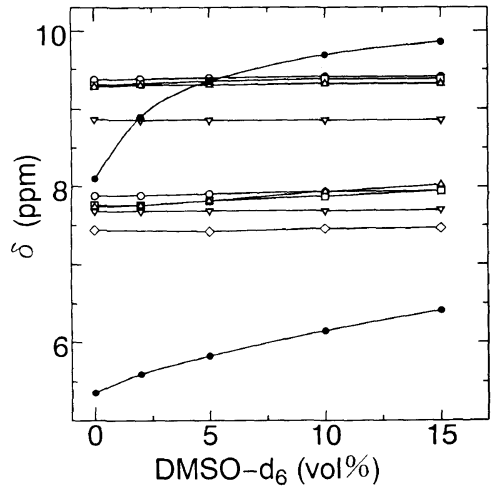

Figure 7. Solvent dependence of $\mathrm{NH}$ chemical shifts in peptide I-5 in $\mathrm{CDCl}_{3}-\left(\mathrm{CD}_{3}\right)_{2} \mathrm{SO}$ mixtures of varying concentration.

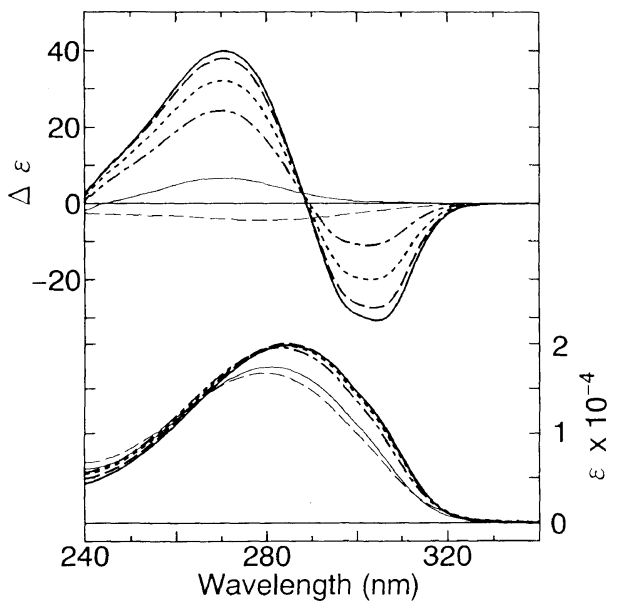

Figure 8. UV absorption (bottom) and $\mathrm{CD}$ (top) spectra of peptides $\mathrm{I}-6(-), \mathrm{I}-5(---), \mathrm{I}-4(-----)), \mathrm{I}-3(-\cdot-\cdot), \mathrm{I}-2(-)$, and I-1 (-- ) in $\mathrm{CHCl}_{3}$.

changed, similarly to peptide I-6. Thus, peptides I-2 to I-5 also favor $3_{10}$-helical-type conformations in $\mathrm{CDCl}_{3}$.

\section{Study}

To get further information on solution conformation, $\mathrm{CD}$ and UV spectra in $\mathrm{CHCl}_{3}$ were measured, as shown in Figure 8. The molar extinction coefficient $(\varepsilon)$ and $\Delta \varepsilon$ $\left(=\varepsilon_{\mathrm{L}}-\varepsilon_{\mathrm{R}}\right)$ are expressed with respect to the molar concentration of the $\Delta^{Z}$ Phe residue.

All absorption spectra showed intense maxima around $280 \mathrm{~nm}$ (band I) assignable to $\Delta^{Z}$ Phe residue. Each $\lambda_{\text {max }}$ and $\varepsilon_{\max }$ are shown in Table II. UV patterns did not change essentially in peptides I- 1 to $\mathrm{I}-6$, while peptides I-3 to I-6 showed slightly longer $\lambda_{\max }$ and larger $\varepsilon_{\max }$. Thus, no strong ground-state interaction between $\Delta^{Z}$ Phe $-\Delta^{Z}$ Phe pair(s) exists in peptides I-2 to I-6. Such interaction was not observed in $3_{10}$-helical sequential peptides containing $\Delta^{Z}$ Phe residues. ${ }^{25}$

The corresponding CD spectra of peptides I-3 to I-6 showed strong exciton couplets with a negative peak at longer wavelengths. The maximum and minimum values of couplets are summarized in Table II. The spectrum of peptide containing only a $\Delta^{\mathrm{Z}}$ Phe residue showed a negative signal around $280 \mathrm{~nm}$. The transition properties of band I are based on an intramolecular chargetransfer interaction between the styryl and carbonyl groups in $\Delta^{Z}$ Phe residue. ${ }^{26}$ The transition moment was estimated from molecular orbital calculation to lie on
Table II. Spectroscopic properties of peptides $\mathrm{I}-n$ in $\mathrm{CHCl}_{3}$

\begin{tabular}{ccccccc} 
& \multicolumn{2}{c}{ UV data } & \multicolumn{5}{c}{ CD data } \\
\cline { 5 - 8 } & $\lambda_{\max } / \mathrm{nm}$ & $\varepsilon_{\max }$ & $\lambda_{\max } / \mathrm{nm}$ & $\Delta \varepsilon_{\max }$ & $\lambda_{\min } / \mathrm{nm}$ & $\Delta \varepsilon_{\min }$ \\
\hline I-1 & 280 & $1.7 \times 10^{4}$ & 278 & -4.5 & - & - \\
I-2 & 281 & $1.7 \times 10^{4}$ & 270 & 6.6 & - & - \\
I-3 & 283 & $2.0 \times 10^{4}$ & 270 & 24.3 & 302 & -11.0 \\
I-4 & 284 & $2.0 \times 10^{4}$ & 270 & 32.1 & 303 & -20.0 \\
I-5 & 284 & $2.0 \times 10^{4}$ & 270 & 38.0 & 304 & -27.3 \\
I-6 & 285 & $2.0 \times 10^{4}$ & 270 & 39.9 & 304 & -30.6
\end{tabular}

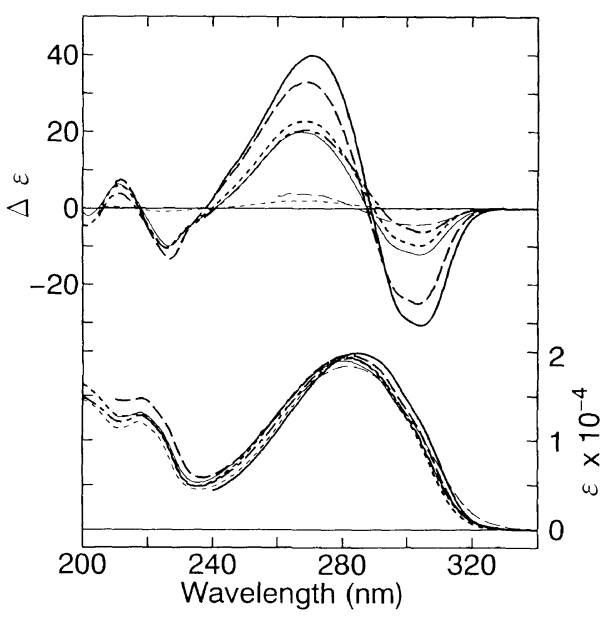

Figure 9. UV absorption (bottom) and CD (top) spectra of peptide I-6 in $\mathrm{CHCl}_{3}(--)$, THF (---), acetonitrile(-----), methanol(---·-), $\operatorname{TMP}(--)$, DMSO (---), and TFE $(-\cdots)$.

the phenyl-carbonyl line. ${ }^{25}$ By applying the exciton chirality method ${ }^{27}$ to the present system, the split CD pattern of peptides I-3 to I-6 corresponds to a righthanded arrangement of the transition moments; i.e., $\Delta^{Z}$ Phe residues are arranged regularly along a righthanded helical main chain. Peptide I-2 showed a nonsplit type CD pattern having only a positive signal at the same wavelength $(270 \mathrm{~nm})$ as in peptides I-3 to I-6. This suggests that a right-handed helix of peptide I-2 is somewhat unstable. Conformational energy calculation on acetyl-(L-Ala- $\left.\Delta^{Z} \mathrm{Phe}\right)_{n}-\mathrm{NHCH}_{3}$ indicated that more stable right-handed helix tends to be formed above $n=2 .^{28}$

Figure 9 shows UV and CD spectra of I-6 recorded in seven different solvents. UV spectra were not affected essentially by the type of solvent. CD spectra was markedly affected by solvents. The CD patterns in THF, acetonitrile, methanol, and TMP were essentially the same as that in $\mathrm{CHCl}_{3}$, while intensity decreased somewhat. Obviously, the helical conformation of I-6 in $\mathrm{CHCl}_{3}$ should be retained in these solvents having various polarities. The patterns in DMSO, and in TFE were essentially different from that in $\mathrm{CHCl}_{3}$, suggesting that the helical structure is broken in such solvents, at least partly. The reason for this might be the stronger hydrogen-bonding nature of DMSO and TFE, which should interfere with the formation of intramolecular hydrogen bonds in helical structures. That helical structures in $\mathrm{CHCl}_{3}$ become unstable in DMSO was also observed for oligopeptides containing two $\Delta^{Z}$ Phe residues. ${ }^{1,13}$ It seems that the rigidity of helical structures induced by introducing $\Delta^{Z}$ Phe residues into peptide 


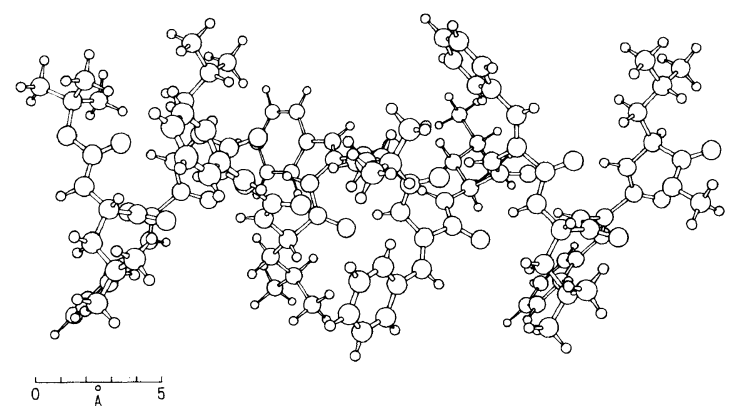

Figure 10. Possible conformation of peptide I-6. The main chain was fixed to a standard $3_{10}$-helix $\left(\phi=-60^{\circ}\right.$ and $\left.\psi=-30^{\circ}\right),{ }^{29.30}$ and the side chain was energy-minimized, using the modified PEPCON program..$^{25,31-33}$

backbones is not very high. However, the introduction of $\Delta^{Z}$ Phe residues obviously induces a helical backbone in the peptides.

\section{Chain-Length Effect on Conformations of $\Delta^{Z}$ Phe- \\ Containing Peptides \\ From the above NMR and CD results, peptide I-6} was shown to form a right-handed $3{ }_{10}$-helical-type structure in $\mathrm{CHCl}_{3}$. Likewise, peptides I-2 to I-5 form such $3_{10}$-type helical structures in $\mathrm{CHCl}_{3}$. Linear pentapeptides of $\mathrm{X}-\Delta^{Z} \mathrm{Phe}-\mathrm{X}-\Delta^{Z} \mathrm{Phe}-\mathrm{X}$, being analogous to peptide $\mathrm{I}-2$, have been found in a $3{ }_{10}$-helical structure in solid state and in solution. ${ }^{7,8,15}$ Thus, the present study shows that such $3_{10}$-helical structure is retained up to the sequential tridecapeptide containing $\mathrm{X}-\Delta^{\mathrm{Z}} \mathrm{Phe}$ units. Here, $\beta$-phenyl groups are arranged regularly along a helical backbone, as shown in Figure 10.

The $\alpha$-aminoisobutyric acid (Aib) residue is widely known to induce the $3_{10}$ - or $\alpha$-helical structure in peptides containing Aib residues. ${ }^{34,35}$<smiles>CC(C)(N)[O-]</smiles>

Aib

Here, torsional angles $(\phi, \psi)$ in Aib residue are severely restricted to the helical region due to steric hindrance of the two methyl moieties. Several Aib-containing peptides showed markedly the chain-length effect on preference for the $310^{-}$or $\alpha$-helical conformation: e.g., in peptides p-bromobenzoyl-(Aib-Ala) $)_{m}-\mathrm{OMe}^{36,37}$ in solid state, peptide $m=3$ is in a complete $3_{10}$-helix, but peptides $m=4-6$ are in an $\alpha$-helix. Also, for peptides Boc(Ala-Aib) ${ }_{m}-\mathrm{OMe}^{38}$ in the solid state, peptide $m=4$ is in a $3{ }_{10}$-type helix, but peptide $m=8$ takes an $\alpha$-helical structure.

In peptides I- $n$, such helix transition was not observed. Sequential polypeptide of (X- $\left.\Delta^{Z} \mathrm{Phe}-\mathrm{Aib}\right)$ suggested a $3_{10^{-}}$to $\alpha$-helix transition in $M W>10^{4} .^{39}$ We shall investigate the solution conformation of sequential polypeptide $\left(\mathrm{X}-\Delta^{Z} \mathrm{Phe}\right)$ to clarify if such helix transition occurs in $\Delta^{Z}$ Phe-containing peptides of longer chains.

\section{CONCLUSIONS}

In the present study, Boc- $\left(\mathrm{X}-\Delta^{Z} \mathrm{Phe}\right)_{n}$-X-OMe $(n=$ $2-6)$ were synthesized, and their solution conformations were investigated by NMR and CD spectroscopy. These peptides were found to form a $30_{10}$-helical-type structure in $\mathrm{CHCl}_{3}$. Namely, using helicogenic $\Delta^{Z} \mathrm{Phe}$ residues, we could make relatively longer $3_{10}$-helical chains (tridecapeptide) where $\beta$-phenyl groups are regularly arranged. This will be useful in the design of functional sequential polypeptides using $\Delta^{Z}$ Phe residues.

Acknowledgment. We express our sincere gratitude to Professor M. Kawai in Department of Applied Chemistry, Nagoya Institute of Technology for the use of CD apparatus.

\section{REFERENCES}

1. K. Noda, Y. Shimohigashi, and N. Izumiya, in "The Peptides," Vol. 5, E. Gross and J. Meienhofer, Ed., Academic Press, New York, N.Y., 1983, pp 286-339.

2. E. Gross and J. L. Morell, J. Am. Chem. Soc., 89, 2791 (1967).

3. H. Allgaier, G. Jung, R. G. Werner, U. Schneider, and H. Zaehner, Eur. J. Biochem., 160, 9 (1986)

4. I. L. Givot, T. A. Smit, and R. H. Abeles, J. Biol. Chem., 244, 6341 (1969).

5. R. B. Wickner, J. Biol. Chem., 244, 6550 (1969).

6. K. R. Rajashankar, S. Ramakumar, and V. S. Chauhan, J. Am. Chem. Soc., 114, 9225 (1992).

7. O. Pieroni, A. Fissi, C. Pratesi, P. A. Temussi, and F. Ciardelli, J. Am. Chem. Soc., 113, 6338 (1991).

8. M. R. Ciajolo, A. Tuzi, C. R. Pratesi, A. Fissi, and O. Pieroni, Biopolymers, 30, 911 (1990).

9. K. K. Bhandary and V. S. Chauhan, Biopolymers, 33, 209 (1993)

10. B. Padmanbhan and T. P. Singh, Biopolymers, 33, 613 (1993).

11. V. S. Chauhan, K. Uma, P. Kaur, and P. Balaram, Biopolymers, 28, 763 (1989).

12. M. R. Ciajoro, A. Tuzi, C. R. Pratesi, A. Fissi, and O. Pieroni, Biopolymers, 32, 717 (1992).

13. A. Gupta, A. Bharadwaj, and V. S. Chauhan, J. Chem. Soc., Perkin Trans. 2, 1911 (1990).

14. A. Tuzi, M. R. Ciajolo, G. Guarino, P. A. Temussi, A. Fissi, and O. Pieroni, Biopolymers, 33, 1111 (1993).

15. O. Pieroni, A. Fissi, C. Pratesi, P. A. Temussi, and F. Ciardelli, Biopolymers, 33, 1 (1993).

16. M. Iqbal and P. Balaram, Biochemistry, 20, 4866 (1981).

17. R. Nagaraj, N. Shamala, and P. Balaram, J. Am. Chem. Soc., 101, 16 (1979).

18. R. Nagaraj and P. Balaram, Biochemistry, 20, 2828 (1981).

19. M. Iqbal and P. Balaram, J. Am. Chem. Soc., 103, 5548 (1981).

20. P. Balaram, A. A. Bothner-By, and J. Dadok, J. Am. Chem. Soc., 94, 4015 (1972) and references therein.

21. K. Wüthrich, "NMR of Proteins and Nucleic Acids," John Wiely \& Sons, New York, N.Y., 1986.

22. J. A. Smith and L. G. Pease, CRC Crit Rev. Biochem., 8, 315399 (1980).

23. T. P. Pinter and D. W. Urry, J. Am. Chem. Soc., 94, 1399 (1972).

24. K. D. Kopple, A. Go, and P. R. Pilipauskas, J. Am. Chem. Soc., 97, 6380 (1975).

25. Y. Inai, T. Ito, T. Hirabayashi, and K. Yokota, Biopolymers, 33, 1173 (1993).

26. O. Pieroni, G. Montagnoli, A. Fissi, S. Merlino, and F. Ciardelli, J. Am. Chem. Soc., 97, 6820 (1975).

27. N. Harada, S. L. Chen, and K. Nakanishi, J. Am. Chem. Soc., 97, 5345 (1975).

28. Y. Inai, K. Hasegawa, T. Hirabayashi, and K. Yokota, in press.

29. Y. Paterson, S. M. Rumsey, E. Benedetti, G. Némethy, and H. A. Scheraga, J. Am. Chem. Soc., 103, 2947 (1981).

30. G. N. Ramachandran and V. Sasisekharan, Adv. Protein Chem., 23, 283 (1968).

31. M. Sisido, private communications

32. F. Momany, R. F. McGuire, A. W. Burgess, and H. A. Scheraga, J. Phys. Chem., 79, 2361 (1975).

33. Y. Beppu, Comput. Chem., 13, 101 (1989).

34. B. V. V. Prasad and P. Balaram, CRC. Crit. Rev. Biochem., 16, 
307 (1984).

35. K. Uma and P. Balaram, Indian J. Chem., 28B, 705 (1989).

36. E. Benedetti, D. B. Benedetto, V. Pavone, C. Pedone, A. Santini, A. Bavoso, C. Toniolo, M. Crisma, and L. Sartore, J. Chem. Soc., Perkin Trans. 2, 1829 (1990).

37. V. Pavone, E. Benedetti, B. DiBlasio, C. Pedone, A. Santini, A.
Bavoso, C. Toniolo, M. Crisma, and L. Sartore, J. Biomol. Struct. Dynam., 7, 1321 (1990).

38. K. Otoda, Y. Kitagawa, S. Kimira, and Y. Imanishi, Biopolymers, 33, 1337 (1993).

39. Y. Inai, T. Ito, T. Hirabayashi, and K. Yokota, Polym. J., 27, 846 (1995). 